\begin{abstract}
The heterogendered cultural discourse that privileges heterosexuality and normalizes sexual and gender binaries damages the science knowledge and opportunities to engage in science learning that children experience in elementary school science. This article analyzes a typical science lesson on crayfish to show how the heterogendered obsession with dichotomies and categorization hides the diversity of sexual morphologies and reproductive processes of the natural world. Furthermore, while sexuality, defined here as an innate desire to satisfy curiosity and use bodily experiences to build knowledge, is a foundation of science, typical elementary school science lessons repress children's curiosity and constrain their embodied understandings. Repairing elementary school science by providing a more expansive view of the diversity of life, inspiring and following children's curiosity, and providing opportunities for children to build embodied knowledge can create a more gender and sex-inclusive curriculum and encourage all children to flourish as learners of science.
\end{abstract}




\section{Repairing Elementary School Science}

In an elementary school science lesson about structures of life, groups of fourth grade students gather around a dish tub inside which crawls a single crayfish in a shallow depth of water. The students peer into the dish tub with a mixture of both excitement and timidity as they observe the crayfish and identify its body structures. Students notice that the crayfish has 8 jointed walking legs, 2 large appendages with pincers, long and short antennae, spherical eyes bulging from the sides of its head, a mouth, an external skeleton, and a segmented abdomen that looks like a tail. On their desks, the students have two worksheets. One asks students to count the number of legs, eyes, pincers, and other body parts on the crayfish. The other worksheet shows a line drawing of 2 crayfish, 1 male and 1 female. Students are supposed to identify the sex of their crayfish and describe differences between the male and the female crayfish body structures. This lesson, from a Full Options Science Systems (FOSS) (Regents of the University of California, 2005) kit and typical of elementary science kit-based lessons ${ }^{1}$, is intended to teach a basic but abstract concept: that in nature, the structure of an object or body part determines how it functions. For example, the hinged structure of a crayfish claw allows it to open and close and the segmented structure of its abdomen lets it curl. At the end of the lesson, the teacher writes on a chart what the class learned about the structure of the crayfish.

With live crayfish in tubs on students' desks, the crayfish lesson appears to be an exciting science lesson. Its hands-on nature is an improvement over lessons that focus solely on reading about crayfish and structure-function concepts from a textbook. While observing the crayfish, students tend to be focused and engaged, rather than bored and disconnected from learning. A

\footnotetext{
${ }^{1}$ FOSS kits are widely recognized and used. Kit-based science curricula produce the same or slightly better student outcomes compared to textbook-based science (e.g., Jones, Robertson, Gardner, Dotger, \& Blanchard, 2012; Young and Lee, 2005).
} 
queer examination of the crayfish lesson, however, shows something different. Queer theory is a lens through which to question what is seen as "normal" in the world (Britzman, 1995;

McWilliams \& Penuel, 2016; Sullivan, 2003). It takes sex, gender, and sexuality as starting points to see how "normal" is socially constructed and how what is seen as "normal" constrains possibilities for understanding the world around us. Bringing a queer perspective into the elementary science classroom shows that even lessons that seem interesting can in fact be damaging to all students in general and to students who have non-normative identities and bodies in particular.

Much of the work on queering science education has focused on how school science narrowly constructs allowable identities (Bazzul \& Sykes, 2011; Fifield \& Letts, 2014; Letts, 1999, 2001; Letts \& Fifield, 2000; Snyder \& Broadway, 2004). This research has shown how the dominant cultural discourses that privilege heterosexuality and portray 2 sexes (male and female) and 2 genders (boys and girls) as binary opposites, which Letts $(1999,2001)$ referred to as heterogendered normativity, harnesses science instruction as a tool for perpetuating the exclusion of non-normative bodies and identities in schools and societies. Explicitly, these groups include children who do not fit into the strict categories of males-who-identify-as-boys or females-whoidentify-as-girls, and children who are developing identities that are outside the perceived "normality" of the heterogendered discourse ${ }^{2}$. They also includes children who come from families with members who are lesbian, gay, bisexual, transgender or questioning/queer (LGBTQ). The work on queering science has focused on disrupting the heterogendered discourse of science in classrooms to help reduce the damage that such discourse does to LGBTQ people.

\footnotetext{
${ }^{2}$ Gender identity and sexual orientation develop throughout childhood (e.g., Carroll, 2018; Martin \& Ruble, 2010).
} 
In this article, I expand on this approach to look at how heterogendered normativity damages the content knowledge and opportunities to engage in science that all children experience in the elementary science curriculum. I argue that sexuality plays an important role in learning about the world. Restricting what and how children are allowed to learn in elementary science hurts all children, not just children who fall outside the heterogendered norms. I provide suggestions for how elementary teachers adjust typical elementary science lessons to not only create a more gender and sexual diversity-inclusive experience in science, but to also repair the damage that an exclusive heterogendered view of science creates and release the full potential of science as a way of knowing about the world.

\section{Repairing Diminished and Damaged Scientific Knowledge}

The obvious place to begin with the crayfish lesson is the way that the lesson emphasizes the differences between female and male crayfish. While the teacher materials suggest that students might also notice differences produced by age and size of the crayfish, the accompanying worksheet highlights the differences between the sexes only. In doing so, the lesson dichotomizes sex and normalizes strict sexual dimorphism (i.e., differences in body type between male and female members of the same species). This lesson is not unique in this focus. A lesson on insects from the same publisher, for example, has students identify the differences between male and female milkweed bugs in a kit on the life cycle of insects. The teachers' guide directs the teacher to explain that when male and female milkweed bugs attach end-to-end they are mating, after which the female will lay clusters of eggs. The message from the milkweed bug lesson is that reproduction requires a male and a female who have different forms and serve different functions based on their sex. 
In the natural world, however, there is great diversity of sex morphologies and reproduction processes. In her book Evolution's Rainbow: Diversity, Gender, and Sexuality in Nature and People, Joan Roughgarden (2013) documented this variety. Numerous examples of organisms cannot be separated into male and female body types. Many insects, for example, look the same whether they are males or females. Some fish can change sexes from male to female (e.g., clownfish) or female to male (e.g., bluehead wrasse), and some fish can do this multiple times in their lives. There are reptiles whose sex is determined by environmental factors, such as the temperature of the environment in which their eggs incubate. Other organisms, such as hamlet fish and barnacles, are hermaphroditic, meaning they are both sexes at the same time. Some mammal species, such as some bears, pigs, dolphins, and hyenas, are intersexed, with sexual organs that are indistinguishable between males and females. Sex roles are not universal either. In some species, such as sea horses, the males carry the eggs and hatch and raise the young. Furthermore, reproduction does not always rely on males and females. Populations of species, such as whiptail lizards, do not have males, relying on cloning of females for reproduction. There are many examples of homosexuality in the animal world as well, including among primates. This enormous diversity defies attempts to classify life into heterogendered male and female categories (Alaimo, 2010).

Yet, in elementary school science, this diversity of life is far from evident. The focus on differences between male and female body types and heterosexual reproduction makes invisible the wondrous variations that populate the natural world, of which humans are a part. In science, Alaimo (2010) argued that heterogendered normativity has "damaged and diminished scientific knowledge" (p. 54) by ignoring the enormous variation among sexed bodies, reproduction, and gendered roles in nature, hiding it instead in the closet of abnormality. So too in elementary 
school science curricula, the heterogendered insistence on rigid classification and binary distinctions damages and diminishes what children are allowed to learn about the diversity of the natural world. As such, the cultural expectation that all people must fit into pre-defined boxes labeled "male/boy" and "female/girl" results in an unproblematized presentation in the elementary school science curriculum of, in these cases, sexual dimorphism among crayfish and heterosexual reproduction of milkweed bugs as representative of the only natural order.

The damage inflicted by strict dichotomization and categorization is not limited to biology topics. The elementary school physical science curriculum, for example, emphasizes classification of matter based on observable properties and typical Earth science lessons focus on the standard classification of 3 types of rocks. As with biology, these disciplines display more diversity of objects of study and less certainty of categories than is portrayed in elementary school science. The heterogendered obsession with distinct boundaries hides the blendings, gradations, and nuances that exist in the universe, ultimately diminishing what students learn to a damaged version of the knowledge they are allowed to know.

This damage has two important implications. First, for children from LGBTQ families and children with non-normative bodies and identities, the focus on rigid boundaries and limited diversity prevents children from seeing themselves and their families reflected in the natural world. Just as importantly, it also severely constrains what all children learn about what is normal, what is wondrous, and what is possible. I contend that disrupting the binary categorization of bodies in elementary school science lessons, such as the one on crayfish, is beneficial for all children and ultimately repairs the knowledge that children learn about the world in which they live. 
Healing this damage requires making visible Roughgarden's rainbow of diversity. Much the way a rainbow has not only multiple colors but also gradations rather than defined boundaries, so too can the elementary science curriculum present the full spectrum of organisms and objects as gradations of differences and overlaps in similarities. In repairing the crayfish lesson so that it becomes less heterogendered and more accurately portrays the amazing diversity of the natural world, a greater emphasis might be placed on noticing other differences among crayfish, not just sexual differences. Children could notice, for example, how some crayfish might be missing a pincer or some crayfish might have different colorings. The lesson could note that there are at least 640 freshwater crayfish species globally that occupy a variety of habitats and have a variety of structures, adaptations, and lifestyles (Crandall \& Buhay, 2008). Children might also be able to compare crayfish structures to structures of other crustaceans (e.g., lobsters, shrimp) or arthropods (e.g., scorpions) to notice both similarities and differences. If comparing male and female specimens, the lesson should note that among the many species of crayfish known, there are species of crayfish with individuals that have both female and male body parts, as well as species of crayfish that change sex during their lifetimes (Yazicioglu, Reynolds, \& Kozák, 2016). ${ }^{3}$ Through these types of changes to the lesson, children would not be presented with pre-defined categories only and sexual dimorphism would not be normalized as the primary distinguishing feature among individuals or as the only normal body type.

\section{Liberating Curiosity and Developing a Feeling for the Organism}

When first encountered, crayfish are bizarre looking creatures. Their segmented bodies, oversized pincers, long antennae, many legs, and bulging eyes make them seem almost alien.

\footnotetext{
${ }^{3}$ In response to those who argue that such inclusion turns science into a sex education course, I point out that the curriculum already contains representations of sex and reproduction, as seen, for example, in the original crayfish lesson.
} 
Some children find them fascinating; others find them repulsive. Either way, their presence in the classroom sparks curiosity and questioning. Children want to know what crayfish eat, where they live, and how they grow. What does a crayfish feel like? How does it walk and swim? How does it make babies? Given the opportunity, children's curiosity about crayfish leads to many questions that can be investigated in the elementary classroom and that lead to the development of new knowledge and understandings about not only crayfish, but also such abstract concepts as structure and function, biological relationships, and evolutionary adaptations.

Psychological research defines curiosity as a desire to satisfy a need to know (Oudeyer, Gottliev, \& Lopes, 2016). This work has shown that people enjoy the pleasurable sense of reward they experience when they satisfy their desire to understand something unexpected. A high sense of curiosity is equated with an intense craving and is a strong intrinsic motivator for learning (Litman, 2005). Building from psychological theories, queer theorists Deborah Britzman (2000) noted that from the moment of birth, humans are motivated by the desire to satisfy basic needs, such as the need for food or the need for love. In the process of getting their needs met, babies use their bodies to learn about the world. As infants come to realize the distinction between themselves and the world around them, the insatiable desire to satisfy curiosity, the need to know more about the world and the pleasure experienced from satisfying that need, grows. It is through using their bodies to satisfy their curiosity that babies develop their knowledge of the world.

The emphasis on the role of bodies in producing knowledge and knowing is important. Lakoff \& Johnson (1980) theorized that embodied knowledge, the knowledge produced by bodily interactions with the physical world, is the basis for all abstract thought. They claimed that humans intuitively understand certain concepts, such as up and down, because of their 
everyday experiences with the world. These physical interactions serve as a metaphor for understanding more abstract concepts, such as gravity. Britzman (2000) argued that the knowledge produced by bodies is not just the result of random movements, but is driven by the physical, emotional, and psychological pleasure produced by satisfying desires. She defined this need and resulting pleasure to satisfy desires as sexuality. In this way, she repurposed sexuality as the force behind bodily explorations and the basis for creating knowledge about the world. This perspective frames sexuality as greater than merely attraction to another person, and instead highlights the fundamental role that sexuality, as defined by desire to know, plays in learning about the world.

As commonly portrayed, scientists are supposed to be objective, unbiased, and dispassionate. However, their talk about their work betrays the pleasure that they feel from satisfying their deep curiosity about the unknown and how their insights are embedded in embodied experiences motivated by their desire to understand. Barbara McClintock, Nobel Prize-winning geneticist, talked about her "feeling for the organism" as the basis for her groundbreaking discovery of recombinant DNA, or jumping genes, from studying corn plants and the ecstasy that she experienced from making her discoveries (Keller, 1983). In a book on the how scientists do their work, Wolpert and Richards (1997) provided multiple examples of the role of passion, desire, and embodied experiences in the work of scientists. For example, applied mathematician Sir James Lighthill, who studied fluid dynamics, talked about how his love for swimming allowed him to have a "general pleasurable feel about fluids" (p. 62) and how his ocean swimming gave him an understanding of waves, currents, and tides. Gerald Edelman, a biologist, said, "Curiosity drives me. I believe that there is a group of scientists who are kind of voyeurs. They have the splendid feeling, almost a lustful feeling, of excitement when a secret of 
nature is revealed." (p. 137). Physicist Carlo Rubbia stated, "We're [scientists] driven by an impulse which is one of curiosity, which is one of the basic instincts....we are driven not by success, but by a sort of passion, namely the desire of understanding better" (p. 197). The emphasis on passion, ecstasy, and lust reveals the role that sexuality, broadly understood as the drive to satisfy curiosity, plays in practicing science and generating of scientific knowledge.

Returning to the crayfish lesson, a queer perspective asks where and how the lesson inspires and satisfies curiosity, and thus motivates children to learn science. In a model enactment of this lesson, available online (Regents of the University of California, 2017), the teacher led the students in making a chart listing what they already knew about crayfish, what they wanted to know about crayfish, and at the end of the lesson, what they learned about crayfish. The students' questions were about what the crayfish eats, how its pincers grow, and how long it takes crayfish eggs to hatch. Beside this list the teacher posted the questions about structure and function that guided the lesson. During the hands-on activity, the children observed the crayfish in the tubs and completed the worksheets. The students were taught how to pick up the crayfish so they could look at its underside to count swimmeret structures. At the end of the lesson, the teacher led the class in listing what they learned about crayfish structures. She wrote, "Structures have functions to help the organism survive." She then returned to the students' list of questions and asked the students what they learned. One child commented that he learned that the crayfish move fast, even if it has only one claw and another said that she learned that crayfish have differences.

At first glance, it seems that since the students were asked what they wanted to learn, their curiosity was engaged in this lesson. However, several points are noteworthy. First, the students did not investigate what they were curious about, but instead were told what structures 
to count on the crayfishes' bodies. Second, students were allowed to pick up the crayfish, but only for the purposes of observing what it looked like. They had little opportunity to interact with the crayfish to find out the things they wanted to find out. Finally, the children's answers to what they learned did not relate to what they listed about what they wanted to learn and what they listed as what they had learned at the end of the lesson showed that what they were curious about during their observations (e.g., how fast crayfish move) had little to do with counting legs or swimmerets. While the lesson may have provided students with the opportunity to see a live crayfish in a tub, possibly for the first time, there were limited opportunities for the students to satisfy their own curiosity about the crayfish.

The crayfish lesson illustrates how romantic notions of childhood purity conspire to repress curiosity in elementary school science (Gunckel, in press). James Sears (1999) wrote, "Childhood innocence is a veneer that we as adults impress onto children, enabling us to deny desire comfortably and to silence sexuality" (p. 9). Similarly, Kerry Robinson (2008) argued that child development stage theory, such as Piaget's cognitive stages, assume a universal, predetermined, biological growth experience that defines what it means to be a child. The child is defined in contrast to the adult. Notions of innocence, naiveté, and vulnerability become assigned to the child and sexuality are constructed as the exclusive domain of adults. This leads to the unquestioned acceptance that children must be protected from their own desires. Thus, the elementary school science curriculum is designed to repress, rather than nourish, children's curiosity. While Britzman (2000) outed the fundamental relationships among sexuality, curiosity, and learning, elementary school science denies children that connection, keeping their curiosity controlled and their sexuality manageably in the closet, thus seriously damaging their opportunities to learn about the world. 
Repressing children's curiosity by mandating the questions asked and prescribing the investigations conducted also limits students' opportunities to build embodied knowledge and use their bodily knowledge to understand abstract concepts, such as how crayfish legs function. In essence, the lesson prevents students from gaining insights through developing their feelings for the organism. In fact, it is difficult to see how counting legs is supposed to help children understand how the structure of legs is related to how crayfish legs function. Children's limited experiences in the lesson with the crayfish constrain the knowledge they are allowed to encounter. The same forces that normalize two sexes, gender-based roles in nature, and heterosexual reproduction isolate children from opportunities to use their bodies to create new understandings, thus confining the knowledge they encounter to the knowledge built by normative bodies and defined by normative experiences (Fifield \& Letts, 2014; Letts, 2001; Letts \& Fifield, 2000; Snyder \& Broadway, 2004). Sanitized of any sense of excitement for the discovery of the unknown, elementary school science instruction becomes the site of (re)production of standardized, often heterogendered versions of science knowledge.

This situation is harmful to children for several reasons. First, it teaches children that the knowledge they learn from their own bodily experiences, if it differs from the normative experience, is not valued. This is especially dangerous to children whose gender and sexuality fall outside the accepted heterogendered norms (Greytak, Kosciz \& Boesen, 2013; Kosciw, Greytak, Diaz, Bartiewicz, 2010). Secondly, repressing children's curiosity denies all children the opportunity to experience the joy of discovery and the pleasure of satisfying a desire to know that scientists experience in their everyday work. From this perspective, scientists are merely individuals lucky enough to retain the curiosity and desire to learn that they had as children. 
Repairing this situation requires introducing sexuality back into the elementary science classroom (Shlasko, 2005). To be clear, I am not talking about teaching children about the act of sex. Rather, I am relying on Britzman's repurposing of the construct of sexuality to argue that resexualizing science means nurturing curiosity and wonder and facilitating opportunities for embodied experiences. For example, instead of asking children what they want to know about crayfish and then telling children to count leg segments, antennae, and eyes to figure out how structures function, the lesson could focus on children's questions and curiosities about crayfish. Finding out what crayfish eat might lead to insights about how crayfish pincers function. Letting children feel how a crayfish walks can lead to embodied knowledge about the structure and function of crayfish legs. Opening opportunities for children to see and experience how crayfish move and then compare that to how their own bodies move can lead to new insights and new questions, building children's own feeling for the organism. Most important, these opportunities also open the door for knowledge built from the experiences of non-normative bodies to have a place at the table and contribute to all children's growing understandings of the world.

\section{Concluding Words}

Science in the elementary curriculum often receives little attention. In the age of standards and accountability, mathematics and language arts, as the tested subjects, are usually prioritized over science instruction (Banilower et al., 2013; Marx \& Harris, 2006). Thus, when thinking about issues related to gender and sexual diversities, LGBTQ people, and creating a more equitable and just world, the elementary science classroom may not be where most people would start to work on building a more inclusive curriculum. But, science is the perfect place to begin re-imagining a curriculum that challenges the hold that heterogendered normativity has on elementary schools. By (re)discovering the full diversity of the natural world, inspiring and 
following children's curiosity, and providing opportunities for all children to have embodied experiences while investigating phenomena, elementary teachers can help repair the damage that heterogendered normativity has inflicted on science learning in elementary classrooms, create a science curriculum that reflects and values LGBTQ people, and open spaces for all children to flourish as learners of science. 


\section{References}

Alaimo, S. (2010). Eluding capture: The science, culture, and pleasure of "queer" animals. In C. Mortimer-Sandilands \& B. Erickson (Eds.), Queer ecologies: Sex, nature, politics, desire (pp. 51-72). Indianapolis, IN: Indiana University Press.

Banilower, E. R., Smith, S. P., Weiss, I. R., Malzahn, K. A., Campbell, K. M., \& Weis, A. M. (2013). Report of the 2012 national survey of science and mathematics education (pp. 309). Chapel Hill, NC: Horizon Research, Inc.

Bazzul, J., \& Sykes, H. (2011). The secret identity of a biology textbook: straight and naturally sexed. Cultural Studies of Science Education, 6, 265-286.

Britzman, D. (1995). Is there a queer pedagogy? Or, stop reading straight. Educational Theory, $45,151-165$.

Britzman, D. (2000). Precocious education. In S. Talburt \& S. R. Steinberg (Eds.), Thinking queer: sexuality, culture and education (pp. 33-59). New York, NY: Peter Lange.

Carroll, J. L. (2018). Sexuality now: Embracing diversity: Cengage Learning

Crandall, K. A., \& Buhay, J. E. (2008). Global diversity of crayfish (Astacidae, Cambaridae, and Parastacidae_-Decapoda) in freshwater. Hydrobiologia, 595, 295-301.

Fifield, S., \& Letts, W. J. (2014). [Re]considering queer theories and science education. Cultural Studies of Science Education, 9, 393-407.

Greytak, E. A., Kosciw, J. G., \& Boesen, M. J. (2013). Putting the "T" in "resource": The benefits of LGBTQ-related school resources for transgender youth. Journal of LGBTQ Youth, 10(1-2), 45-63.

Gunckel, K. L. (In Press). What does queer theory have to do with teaching science in elementary schools? In S. Fifield \& W. Letts (Eds.), STEM of Desire: Queer Theories in Science Education. Rotterdam, Netherlands: Springer. 
Jones, G., Robertson, L., Gardner, G. E., Dotger, S., \& Blanchard, M. R. (2012). Differential use of elementary science kits. International Journal of Science Education, 34(15), 23712391.

Keller, E. F. (1983). A feeling for the organism. New York: W.H. Freeman.

Kosciw, J. G., Greytak, E. A., Diaz, E., \& Bartkiewicz, M. J. (2010). The 2009 national school climate survey: Key findings on the experiences of lesbian, gay, bisexual and transgender youth in our nation's schools. New York, NY: Gay, Lesbian and Straight Education Network.

Lakoff, G., \& Johnson, M. (1980). Metaphors we live by. Chicago: University of Chicago Press.

Letts, W. J. (1999). How to make "boys" and "girls" in the classroom: The heteronormative nature of elementary-school science. In W. J. Letts \& J. Sears (Eds.), Queering elementary education: Advancing dialogue about sexualities and schooling (pp. 97-110). New York, NY: Rowman \& Littlefield.

Letts, W. J. (2001). When science is strangely alluring: Interrogating the masculinist and heteronormative nature of primary school science. Gender and Education, 13, 261-274.

Letts, W. J., \& Fifield, S. (2000, April). Sexualities, silence, and science teacher education. Paper presented at the American Educational Research Association, New Orleans.

Litman, J. (2005). Curiosity and the pleasures of learning: Wanting and liking new information. Cognition \& emotion, 19(6), 793-814.

Martin, C. L., \& Ruble, D. N. (2010). Patterns of gender development. Annual Review of Psychology, 61, 353-381.

Marx, R. W., \& Harris, C. J. (2006). No Child Left Behind and science education: Opportunities, challenges, and risks. The Elementary School Journal, 106, 467-478. 
McWilliams, J., \& Penuel, W. R. (2016). Queer theory in the learning sciences. In I. Esmonde \& A. N. Booker (Eds.), Power and Privilege in the Learning Sciences: Critical and Sociocultural Theories of Learning (pp. 93-114). New York, NY: Routledge.

Oudeyer, P.-Y., Gottlieb, J., \& Lopes, M. (2016). Intrinsic motivation, curiosity, and learning: Theory and applications in educational technologies. In B. Studer \& S. Knecht (Eds.), Progress in brain research (Vol. 229, pp. 257-284). Amsterdam, Netherlands: Elsevier. Regents of the University of California. (2005) FOSS Kit Structures of Life: Investigation 3: Meet the Crayfish. Hudson, NH: Delta Education.

Regents of the University of California. (2017). Meet the Crayfish Lesson. from https://education.ucsc.edu/ellisa/case_studies/crayfish-lesson-1a.html

Robinson, K. H. (2008). In the name of 'childhood innocence': A discursive exploration of the moral panic associated with childhood and sexuality. Cultural Studies Review, 14(2), 113.

Roughgarden, J. (2013). Evolution's rainbow: Diversity, gender, and sexuality in nature and people. Berkeley, CA: University of California Press.

Sears, J. (1999). Teaching queerly: Some elementary propositions. In J. Sears \& W. J. Letts (Eds.), Queering elementary education: Advancing dialogue about sexualities and schooling (pp. 3-14). New York, NY: Rowman \& Littlefield.

Shlasko, G. D. (2005). Queer (v.) pedagogy. Equity \& Excellence in Education, 38, 123-134.

Snyder, V., \& Broadway, F. S. (2004). Queering high school biology textbooks. Journal of Research in Science Teaching, 41, 617-636.

Sullivan, N. (2003). A critical introduction to queer theory. New York, NY: New York University Press. 
Wolpert, L., \& Richards, A. (1997). Passionate minds: The inner world of scientists. New York, NY: Oxford University Press.

Yazicioglu, B., Reynolds, J., \& Kozák, P. (2016). Different aspects of reproduction strategies in crayfish: A review. Knowledge and Management of Aquatic Ecosystems, 417(33), 1-15.

Young, B. J., \& Lee, S. K. (2005). The effects of a kit-based science curriculum and intensive science professional development on elementary student science achievement. Journal of Science Education and Technology, 14(5-6), 471-481. 


\section{Additional Resources for Classroom Use}

Seemel, G. (2012). Crimes against nature. Portland, OR: Author. http://www.gwennseemel.com/index.php/pages/from/category/nature_book/

This book, written for children, displays the amazing diversity of the animal kingdom in vivid paintings by painter Gwenn Seemel. Forwarded by Joan Roughgarden, it is a visual compliment to the Roughgarden's Diversity's Rainbow. The book can be ordered from the author/artists's website. There is also an e-book version available online.

Kim, K. H. (2017). Want to foster creativity in children? Science says, "Nurture curiosity!" The Creativity Post.

http://www.creativitypost.com/education/want_to_foster_creativity_in_children_science_says_n urture_curiosity

This is a blog post that provides an extensive list of tips and ideas for teachers and parents for nurturing children's curiosity.

Tracy, K. (2002). Barbara McClintock: Pioneering Geneticist, Hallandale, FL: Mitchell Lane Publishers.

This middle-grades biography tells the story of how Barbara McClintock worked in obscurity as a woman scientists in a field dominated by men, how she discovered jumping genes, and how she eventually won the Nobel Prize twenty years later. The book provides a starting point for discussions about how scientists rely on empirical observations as well as passion and intuition to make discoveries. 